Pamiętnik Literacki 2020, 1, s. 271-280

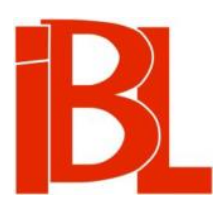

\title{
Halina Krukowska
}

(26 września 1937 - 28 lipca 2019)

Jarosław Ławski 


\section{HALINA KRUKOWSKA (26 września 1937 - 28 lipca 2019) WSPOMNIENIE}

\section{Osobowość}

Odeszła 28 lipca 2019. Profesor Halina Krukowska była najbardziej wyrazistą osobowością polonistyki białostockiej. Wraz z jej śmiercią, a wcześniej z odejściem jej rówieśnicy, prof. Elżbiety Feliksiak, zamknęła się epoka w dziejach środowiska filologicznego, które obie uczone współtworzyły niemal od samego początku i któremu nadawały ton ${ }^{1}$. Profesor Krukowską należy nazwać współtwórczynią podlaskiej polonistyki i w pełni twórczynią białostockich badań nad literaturą romantyzmu. Nade wszystko była legendarną postacią białostockiego środowiska naukowego.

Chciałbym jednak, by poza przywołaniem dokonań wybrzmiało tu coś jeszcze o samej Halinie Krukowskiej: była wielka, oryginalną osobowością, człowiekiem dobrym, o przenikliwej inteligencji i niezwykłej precyzji myślenia. Wiele wymagała od siebie, dlatego wiele mogła wymagać od innych. Znana była w swym środowisku z nieustępliwej, szlachetnej prostolinijności i prawdomówności. Zawsze mówiła to, co myśli, nawet jeśli u większości nie znajdowało to poklasku. Nie tylko na Uniwersytecie, lecz i w działalności publicznej za kierunkowskaz uważała Prawdę. To kazało jej przez całe życie przeciwstawiać się, jak z emocjami mówiła, „komunie”. Zaangażowała się w organizowanie struktur NSZZ „Solidarność”, a po 13 XII 1981 w pomoc uwięzionym, internowanym. W stanie wojennym komisja weryfikacyjna negatywnie oceniła jej postawę polityczną i predyspozycję do pracy w „socjalistycznym państwie". Zawsze chciała, by dla przestrogi przypominać, że komisję tę tworzyli jej jeszcze niedawni koledzy $z$ uczelni.

Lubiła zaznaczać, iż należy do określonej formacji intelektualnej i duchowej: iż jest reprezentantką tradycji patriotycznej i katolickiej. Nigdy nie towarzyszył temu dystans do osób inaczej myślących, niewierzących. Przeciwnie - w wielonarodowym i wielowyznaniowym środowisku podlaskim kształciła osoby o najróżniejszych poglądach, przynależnościach konfesyjnych, postawach: katolików, prawosławnych, agnostyków i (co też bywało) ateistów. Wielu z nich zachowuje we wdzięcznej pamięci doświadczenie spotkania ze znakomitą uczoną i pełnym pasji pedagogiem, jakim była autorka Nocy romantycznej. Angażowała się w działalność białostockie-

1 Obie zostały przez swoje środowisko uhonorowane księgami, jubileuszami. Zob. Światło w dolinie. Prace ofiarowane Profesor Halinie Krukowskiej. Red. K. Ko r o tk i c h, J. Ław s ki, D. Zaw a d zk a. Białystok 2007. - Literatura, pamięć, kultura. Prace ofiarowane Profesor Elżbiecie Feliksiak. Red. E. Sidoruk, M. M. Leśs. Białystok 2010. Zob. też V. W ej s-Milew s ka, Elżbieta Feliksiak (1937-2015). „Wiek XIX” 2014. 
go Klubu Inteligencji Katolickiej, gdzie stale wygłaszała odczyty o duchowym wymiarze literatury oraz współredagowała jego pismo „Słowo”.

Szczyciła się tym, iż jest uczennica prof. Marii Janion. W innych kategoriach postrzegając od lat osiemdziesiątych XX wieku świat i literaturę, akcentowała publicznie, iż prof. Janion pozostaje dla niej „niedoścignionym wzorem nauczyciela akademickiego" ${ }^{2}$. Jak powtarzała, jej Mistrzyni (nieodmiennie przez wielkie „M”) „była zawsze przygotowana, i to jak!”. Pasją pedagogiczną sama była zarażona - bez reszty emocjonowała się dyskusjami na temat kolejnych „reform” oświaty, publikowała teksty pokazujace alternatywne kierunki zmian ${ }^{3}$. Białostockie licea (w tym szczególnie LO nr $1 \mathrm{im}$. Adama Mickiewicza) miały w niej niezawodna prelegentkę. Interesowała się problemem kształcenia nauczycieli na uniwersytetach, działała aktywnie w Towarzystwie Literackim im. Adama Mickiewicza (Oddział Białostocki).

Miała - przy całej swej pryncypialności - dar przyciagania ludzi, szczególnie młodych, zafascynowanych jej osobowością i zupełną wyjątkowością. Była znakomitym, lecz bardzo rzadkim typem wykładowcy. Wymagała od studentów, magistrantów i doktorantów tak dużo, iż niewielu z nich udawało się jej oczekiwania spełnić. Egzamin z literatury romantyzmu był owiany „czarna” legenda najtrudniejszego na polonistyce białostockiej. Tak było aż do połowy lat dziewięćdziesiątych, kiedy pozwoliła odpytywać studentów młodym, wtedy właśnie zatrudnianym asystentom. Jej seminaria magisterskie miały najwyższy poziom, a magisterium napisane pod kierunkiem Pani Profesor było powodem do chluby. Zdarzało się, że na niektórych studentów piszących magisterium patrzyła jakby $z$ większą łagodnością, ale były to wyjątki. Kto przeszedł jej seminarium, zapamiętywał je do końca życia, a z każdym rokiem obraz surowej Pani Profesor ulegał idealizacji, ,romantyzacji”.

Najzupełniej obce było jej słowo „kariera”. Krukowska jako pierwsza literaturoznawczyni w 50-letnich dziejach białostockiego środowiska filologicznego zrobiła habilitację. Przyznawała, iż zmobilizował ją do tego stan wojenny i ponure lata po nim. Nie chciała słyszeć, pomimo stałych zachęt ze strony kolegów, o podjęciu starań o profesurę belwederska (jest to jedna z rzeczy, do których nie udało mi się jej przekonać). Nie interesowały jej, co podkreślała, „tytuły”, fascynowały za to przejawy - jak lubiła mówić - „życia duchowego człowieka w literaturze, a szczególnie poezji”. Sama - choć niezmiernie rzadko - pisała wiersze, które niechętnie pokazywała, i to tylko najbliższym, nazywając je „zapisami snów”. Jej pasją było przede wszystkim językoznawstwo. Uwielbiała także kino. Znana też była z innych, zgoła nieliterackich, zaskakujących zamiłowań - znakomicie uzdolniona technicznie, lubiła majsterkować, remontować, naprawiać swój samochód ${ }^{4}$. Kiedy w stanie

Oczywiście na słynnym „drzewie” przedstawiającym uczniów prof. Janion znajdziemy prof. Krukowską i jej wychowanków. Zob. też H. Kr u k ow s k a, „Balladyna” Juliusza Słowackiego w świetle rozprawy Alfreda de Vigny. Rozważania o prawdzie w sztuce. W zb.: Księga Janion. Oprac. Z. Majchrowski, S. Rosi ek. Gdańsk 2006.

3 Zob. H. Kruk ow s ka: Jaki powinien być polonista? „Tygodnik Kulturalny” 1975, nr 14; Nowa matura z języka polskiego. „Kurier Poranny” 2005, nr z 25 I.

4 O różnych pasjach Krukowskiej zob. artykuły w zb. Światło $w$ dolinie: J. Ła w s ki, Homo nocturnus. Romantyzm Haliny Krukowskiej. - D. Ku les z a, Stowo. Nie tylko o wierszach Pani Profesor Haliny Krukowskiej. - I. Szcze pankow s ka, Właściwości języka poetyckiego w rozprawach 
wojennym chciano ją wyrzucić $z$ pracy na Uniwersytecie, postanowiła założyć warsztat stolarski. Wiele rzeczy do własnego gabinetu wykonała sama.

Miała dar organizacyjny: stworzyła działającą od 1993 roku do dziś Naukowa Serię Wydawniczą „Czarny Romantyzm”, w której ukazało się już prawie 50 tomów sławnych i zapomnianych dzieł z ciemnego nurtu. Kierowała zakładami, w powołaniu dwóch uczestniczyła, objęła kierownictwo Instytutu Filologii Polskiej na białostockiej uczelni. Trzeba powiedzieć, iż jakkolwiek rozmaicie układały się rela-

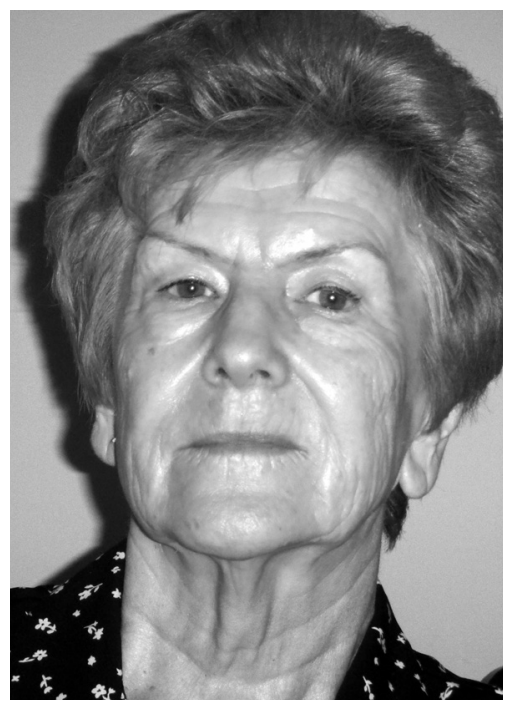

Halina Krukowska

cje $z$ ludźmi, których zatrudniała na uczelni, to jednak dzięki niej na Filii Uniwersytetu Warszawskiego, a potem na Uniwersytecie w Białymstoku zatrudniono spore grono jej uczniów, przyjaciół i współpracowników. Wymienić trzeba: dr. Zbigniewa Suszczyńskiego (1958-2009) ${ }^{5}$, dr hab. Danutę Zawadzką, prof. UwB, dr hab. Elżbietę Dąbrowicz, prof. UwB, dr. Krzysztofa Korotkicha, dr Barbarę Sawicką-Lewczuk, dr. Marcina Bajkę, dr. Marcina Lula oraz niżej podpisanego ${ }^{6}$. Interesowała się ich losem, nigdy nie potrafiła o bliskich jej pamięci osobach myśleć źle, przeciwnie: szukała tego, co dobre, zachowując zarazem postawę oddalenia od spraw bieżących, uważała bowiem, że nie wypada jej się angażować w życie samodzielnie działających ludzi (poza sytuacjami, gdy wymagali pomocy, wtedy gotowa była nieść ją każdemu).

Pani Profesor Haliny Krukowskiej - spojrzenie językoznawcy. - D. Za w a d z k a, Poczwarka faktu i motyl fikcji - parę uwag o historii według romantyków.

5 Zob. I. A u t u c hi e w i c z, Zbigniew Suszczyński. Hasło w: Encyklopedia Solidarności. Na stronie: http://www.encysol.pl/w/index.php (data dostępu: 09 IX 2019).

$6 \quad$ Krukowska była ponadto zaangażowana w zatrudnieniu na uczelni m.in. dr. hab. Piotra Stasiewicza, dr hab. Anny Wydryckiej, dr Katarzyny Sokołowskiej, dr. Wojciecha Wądołowskiego. 
Osoby znające Krukowską wiedziały, że ma dwóch poetów, których „kocha nad życie". Przede wszystkim Adama Mickiewicza. Uważała go, słusznie przecież, za jednego z najważniejszych liryków literatury powszechnej, a Pana Tadeusza za trudny do pojęcia fenomen poezji czystej ${ }^{7}$. Mickiewicz stał się dla Krukowskiej wzorem postaw obywatelskich, przywódczych. Jak on, umiała mądrze i bezkompromisowo krytykować to, co ceniła, do czego przynależała: uniwersytet, instytucje kościelne, władze, szkołę, świat sztuki. Drugim arcypoetą Krukowskiej był autor genialnej Marii, Antoni Malczewski. Należała, jak powiadała, razem z nami, jej uczniamii, do tajemnego bractwa miłośników Marii, do „partii Malczewskiego”. Poemat, a pisała o nim tylko z pasją, wyrażał jej i nasza prawdę o tragizmie i ostatecznie daremności egzystencji, niepewności, kresie, którym człowiek może przeciwstawić tylko pokorę poematowej Marii, kenotyczne uniżenie Miecznika na grobie córki i żony oraz mistycznie zabarwione intuicje religijne. Krukowska powtarzała często słowa Pieśni Masek: „Bo na tym świecie Śmierć wszystko zmiecie, / Robak się lęgnie i w bujnym kwiecie" ${ }^{8}$. Fascynacja Mickiewiczem i Malczewskim, egzystencjalną stroną ich poezji, radykalizmem wyborów życiowych, postaw politycznych i poznawczych (mistyka/nihilizm) przekonywała nas do Pani Profesor. W jej egzaltacji duchowej, miłości do literatury i pięknie jej umysłu czysto myślącego o najbardziej abstrakcyjnych kwestiach nie było ani jednej fałszywej nuty. Okazała się prawdziwa całą swą osobowością. Indywidualistką w każdym calu, skądinąd też była autorką hasła Indywidualizm w Stowniku literatury polskiej XIX wieku ${ }^{9}$.

Bardzo rzadko Krukowska wracała do wczesnego dzieciństwa, naznaczonego wojną. Właściwie wspominała je dopiero krótko przed śmiercią. W ostatnim $z$ wywiadów mówiła:

Doświadczyłam wielu trudów i represji wojennych i powojennych. Przeżyłam Sowietów, Niemców, którzy notabene mieli w naszym pokoju swoją maszynerię nadawczo-odbiorczą, przez co żyliśmy wówczas w nieustannym strachu. Później, kiedy wojna się skończyła, niby był to rok pokoju, 1945, lecz dzieciństwo spędzało się w schronach. Dla dzisiejszej młodzieży słowo „schron” nie znaczy nic niepokojącego, wręcz przeciwnie, A nasze dzieciństwo to było uciekanie od schronu do schronu [...]. Bardzo dotkliwie przeżyłam fakt dojścia do władzy i utrzymania jej przez komunę. Nie wiem dokładnie, kiedy to się stało, ale moja ulica, która od zawsze nazywała się Grodzieńska, jak tylko weszła komuna, przemianowana została na Juliana Marchlewskiego. Nigdy nie mogłam zrozumieć, na jakiej zasadzie nastąpiła zmiana nazw ulic. To było dla mnie tak duże przegięcie, i sama komuna, i to kłamstwo otaczające mnie, że zapragnęłam ucieczki od rzeczywistości, która mnie otaczała, i wejścia w świat literatury, która był wspaniała, $\operatorname{czysta}^{10}$.

7 H. Kruk ow ska poświęciła temu dziełu swą słynną rozprawę, która ostatecznie dała tytuł tomowi jej prac: „Pan Tadeusz” jako poezja czysta. Studia i szkice o Mickiewiczu. Białystok 2016 (pierwodruk: 1993). Zob. J. Ła wski, $Z$ ducha Karpińskiego: Haliny Krukowskiej interpretacje „Pana Tadeusza”. W zb.: Z ducha Franciszka Karpińskiego. Studia i rozmowy. Red. D. Kule s za, J. Ławski. Białystok 2015.

8 A. Malczewski, Maria. Powieść ukraińska. Wprowadzenie H. Krukowska, J. Ławski. Wyd. 2. Białystok 2002, s. 157. Zob. Antoniemu Malczewskiemu $w$ 170. rocznice pierwszej edycji „Marii”. Materiały sesji naukowej, Biatystok 5-7 V 1995. Red. H. Kr u k ow s ka. Białystok 1997.

9 H. Krukows ka, Indywidualizm. Hasło w: Stownik literatury polskiej XIX wieku. Red. J. Bac hór z, A. Kow al czy kowa. Wrocław-Warszawa-Kraków 1994. Hasło zrazu omyłkowo przypisano w kilku wydaniach Stownika innemu autorowi.

10 „Człowiek to przepaść, której nie można zasypać”. Rozmowa z prof. Halina Krukowska. Rozmawiał Ł. Zabielski [2018]. Tekst niepublikowany. 
Była, rzec można, osobą pryncypialną, nieustępliwą, nie uznawała kompromisów, kiedy chodziło o Prawdę (tak właśnie pisaną). Jak cierń tkwiło w Krukowskiej, często przypominane, doświadczenie wyrzucenia ze szkoły w okresie stalinowskim:

jakimiś sobie tylko znanymi drogami mój ojciec wystarał się o miejsce dla mnie w Liceum im. Towarzystwa Przyjaciół Dzieci w Białymstoku. Było to „czerwone” liceum. w pełni tego słowa znaczeniu: stalinowskie. Młodzież nosiła tam medaliki ze Stalinem. I kiedy Stalin umierał, powiedziałam bardzo krytyczne o nim zdanie, co rozpoczęło całą serię nieszczęść w moim życiu. Zaczęłam być wzywana przez dyrektora, zmuszana do tłumaczenia się. Co więcej, klasa mnie sądziła, nazwała „czarną reakcją”. Było to bardzo nieprzyjemne doświadczenie. A najbardziej przygnębiającym doznaniem był moment, kiedy wybrani nauczyciele tej szkoły, którzy nie mieli ze mną lekcji, przychodzili, otwierali drzwi klasy i pytali, która to jest Krukowska, po czym oglądali mnie jak jakieś egzotyczne zwierzę. Głośno zastanawiali się, jakim to sposobem w ich szkole znalazła się osoba, która ośmieliła się powiedzieć coś o Stalinie. [...] Rada pedagogiczna podjęła decyzję o usunięciu mnie ze szkoły 12 marca 1953 roku. Przypomnę, że Stalin umarł 5 marca tegoż roku. Ostatecznie zostałam usunięta ze szkoły z dwuletnim zawieszeniem w czynnościach uczennicy ${ }^{11}$.

Krukowska stała się potem w PRL-u obiektem ataków ze strony władz różnego szczebla, zawsze jako nieustępliwa antykomunistka.

Jej droga do nauki okazała się bardzo trudna. Lata studiów, jak nam opowiadała, były latami biedy, niedostatku, lecz i wielkiej pasji czytania, zachwycenia literaturą.

\section{Prace}

Halina Krukowska ukończyła filologię polską w Wyższej Szkole Pedagogicznej w Gdańsku. Pod kierunkiem Marii Janion napisała rozprawę magisterską „Matka Joanna od Aniołów" Jarosława Iwaszkiewicza. Próba monografii. Po studiach otrzymała stypendium oraz propozycję uczestniczenia w pracach seminarium doktoranckiego na Uniwersytecie Gdańskim. W roku 1970 uzyskała stopień doktora nauk humanistycznych na podstawie dysertacji Funkcje stylistyczne składni w powieści poetyckiej wczesnego romantyzmu (promotor: prof. Maria Janion, recenzenci: prof. Maria Renata Mayenowa i prof. Czesław Zgorzelski). Stopień doktora habilitowanego otrzymała na podstawie rozprawy Noc romantyczna (Mickiewicz, Malczewski, Goszczyński). Interpretacje (wyd. 1: Białystok 1985; wyd. 2: Gdańsk 2011). Kolokwium habilitacyjne odbyło się na Uniwersytecie Warszawskim, pracę recenzowały prof. Maria Żmigrodzka, prof. Maria Grabowska i prof. Maria Janion. Książka o Nocy romantycznej stała się jednym z dokonań życia Krukowskiej. Była cytowana, komentowana, znana w zagranicznych ośrodkach slawistycznych. Podobnie rzecz się miała z tomami „Czarnego Romantyzmu”, które bardzo szybko zyskały uznanie i w kraju, i za granica.

W roku 1969 podówczas mgr Krukowska związała się z powstałą rok wcześniej Wyższą Szkołą Nauczycielską w Białymstoku. Na jej fundamencie uruchomiono Filię Uniwersytetu Warszawskiego w Białymstoku, a następnie, w 1997 roku, powołano samodzielny Uniwersytet w Białymstoku. W latach 1969-1985 bez reszty pochłonęła Krukowską dydaktyka. W roku 1988, w 190 rocznicę urodzin Mickiewicza, zorganizowała pamiętną sesję poświęconą poecie, którą tak wspominała: 
Przyjechali najwybitniejsi badacze literatury. Wśród tych osobistości byli: prof. Zbigniew Sudolski, prof. Józef Bachórz, prof. Marta Piwińska, prof. Stanisław Makowski. To wydarzenie wielkiej wagi dla romantyzmu białostockiego, ponieważ na tej sesji wytworzyła się niezwykła atmosfera czci dla Mickiewicza. [...] Otrzymałam nawet list od profesora Samuela Fiszmana z Department of Slavic Languages and Literatures na Indiana University w Bloomington z prośbą, by na język angielski przetłumaczyć moją rozprawę o Panu Tadeuszu ${ }^{12}$.

Tytuł profesora Uniwersytetu w Białymstoku otrzymała w 1995 roku. W latach kolejnych kierowała Zakładem Literatury Polskiej. Z jej inicjatywy powołano, już po przekształceniu Filii UW w Uniwersytet), niezależny Zakład Literatury Oświecenia i Romantyzmu (2000). Jego kierownikiem Krukowska była do roku 2007. Z tego Zakładu wyłoniła się z kolei kierowana przeze mnie Katedra Badań Filologicznych „Wschód - Zachód”, której współpracownikiem Pani Profesor pozostała do końca. Pełniła funkcję dyrektora Instytutu Filologii Polskiej UwB (1999-2002), należała do wydziałowej komisji dyscyplinarnej i komisji oceniajacej. Z inicjatywy Krukowskiej Instytut rozwiną stałą współpracę ze środowiskiem nauczycielskim Białegostoku i Podlasia.

Dr hab. Krukowska w roku 1993 zainaugurowała prace Redakcji Naukowej Serii Wydawniczej „Czarny Romantyzm” ${ }^{13}$, której przez lata pozostawała redaktorem naczelnym. Do śmierci pełniła funkcje przewodniczącej Rady Redakcyjnej. W latach 2012-2017 kierowała grantem Narodowego Programu Rozwoju Humanistyki pod nazwą Krytyczna edycja wybitnych, zapomnianych dzieł XIX-wiecznej polskiej literatury romantycznej $w$ NSW „Czarny Romantyzm”. W ramach tego projektu wydano 10 tomów tekstów źródłowych z XIX wieku w opracowaniu krytycznym. Kierując grantem, prof. Krukowska napisała bardzo obszerny wstęp do edycji krytycznej Lesława Romana Zmorskiego, redagowała tomy dramatów Wacława Szymanowskiego, polsko-angielskie wydanie Myśli nocnych Edwarda Younga, pierwsze po 200 latach wznowienie Edmunda Stefana Witwickiego ${ }^{14}$. Wkrótce została kierownikiem kolejnego projektu NPRH, Kontynuacja krytycznych edycji wybitnych, zapomnianych dziet XIX-wiecznej polskiej literatury romantycznej $w$ NSW „Czarny Romantyzm" w XII tomach (2018-2022). Tej pracy już nie dokończy. To dzięki jej staraniom tylko w ramach tych dwu grantów uda się wydać 22 tomy rzadkich, nie wznawianych dotąd dzieł romantycznych. Nadto Krukowska wchodziła w skład Rad Naukowych dwóch serii wydawniczych: „Colloquia Orientalia Bialostocensia” oraz „Przełomy/Pogranicza. Studia Literackie”.

H. Krukowska, Z Mickiewiczowskiego ducha. W zb.: Białostockie środowisko filologiczne 1968-2018. Historia w 45 wywiadach. Rozmawiał D. Sołowiej. Red. J. Ławski. Białystok 2018, s. 209. List prof. S. Fis zmana w: D. Rembiszews ka, K. Szamryk, Z materiałów Samuela Fiszmana. „Slavia Orientalis” 2019, nr 1.

13 Zob.t. 1 serii: S. Gos zczyń ski, Zamek kaniowski. Wprowadzenie H. Krukowska. Białystok 1994.

14 Zob. R. Zmorski, Lesław. Szkic fantastyczny. Wstęp i oprac. tekstu H. Krukowska. Red. J. Ławski. Białystok 2014. - W. Szymanowski, Michał Sędziwój (Dramaty). Wstęp

G. Czerwiński, A. Janicka. Red. J. Lawski, H. Krukowska. Białystok 2015. -

E. Young, Myśli nocne. Wstęp M. Sokołowski, Ł. Zabielski. Red. H. Krukowska, J. Ławski. Białystok 2016. - S. Witwicki, Edmund. Wstęp M. S ok ołowski. Wprowadzenie M. Burzka-Janik. Red., przypisy H. Krukowska. Białystok 2015. 
Z inicjatywy badaczki zorganizowano wiele ogólnokrajowych sesji naukowych. Kilka z nich - piszę bez przesady - weszło do dziejów polonistyki: Mickiewicz. W 190-ta rocznice urodzin (Białystok, 2-4 XII 1988); Antoni Malczewski. Poeta poemat-recepcja. W 170 rocznice śmierci poety 1826-1996 (Białystok, 5-7 V 1995); Postaci i motywy faustyczne $w$ literaturze polskiej (Białystok, 23-26 X 1997); Problemy tragedii i tragizmu $w$ aspekcie teoretycznym $i$ historycznoliterackim (Białystok, 22-24 XI 2001).

Prof. Krukowska wypromowała około 220 magistrów oraz 2 doktorów nauk humanistycznych (dr Barbara Sawicka-Lewczuk i dr Jarosław Ławski). Przez wiele lat należała do kapituły przyznającej Nagrodę Literacką Prezydenta Miasta Białegostoku im. Wiesława Kazaneckiego, a od 2017 roku do Rady Naukowej Książnicy Podlaskiej im. Łukasza Górnickiego w Białymstoku.

Jej zainteresowania naukowe obejmowały literaturę polskiego i europejskiego romantyzmu ze szczególnym uwzględnieniem twórczości Mickiewicza, poetów „szkoły ukraińskiej” (Malczewski, Goszczyński, Zaleski) ${ }^{15}$, problematykę duchowości artystów romantycznych, ich religijności, nocną, melancholijną stronę wyobraźni poetów polskich, a także inspiracje mistyki wschodniochrześcijańskiej w literaturze polskiej oraz romantykę niemiecka.

26 X 2007 została uhonorowana wspaniałym jubileuszem i liczacca ponad 700 stronic ksiegga Światło w dolinie. Częścia jubileuszu stała się konferencja naukowa Wokót "Straży nocnych” Bonawentury. Romantyzm polski i europejski wobec romantyzmu niemieckiego. Sesja jubileuszowa dedykowana Profesor Halinie Krukowskiej (25-26 X). Jej owocem jest też dwutomowa monografia Noc. Symbol - temat - metafora (Białystok, t. 1: 2011, t. 2: 2012).

Po przejściu na emeryturę otrzymała tytuł profesora seniora i rzuciła się z pasją w wir pracy naukowej, w pisanie i wydawanie dzieł literatury XIX wieku. Wyróżniona została Ogólnopolską Nagrodą Literacką im. Franciszka Karpińskiego (2007) za wybitne osiągnięcia w badaniach nad poezją religijną i liryką romantyczną w Polsce. 3 XII 2018 została odznaczona Medalem Stulecia Odzyskanej Niepodległości.

Do końca pozostała aktywna twórczo, publikując książki naukowe („Pan Tadeusz" jako poezja czysta. Studia i szkice. Białystok 2016) oraz liczne rozprawy literaturoznawcze ${ }^{16}$.

Za istotne badaczka uważała publikacje: Mickiewicz. W 190-lecie urodzin. Materiały z sesji naukowej. Białystok, 2-4 grudnia 1988. Red. H. Kr u k ow s k a. Białystok 1993. - Postaci i motywy faustyczne $w$ literaturze polskiej. Materiały Ogólnopolskiej Konferencji Naukowej. Białystok 23-26 października 1997 r. T. 1-2. Red. H. Kr u k ow s k a, J. Ław s ki. Białystok 1999-2001. - Problemy tragedii i tragizmu. Studia i szkice. Red. H. Krukowska, J. Ławski. Białystok 2005. Historia literatury polskiej $w$ dziesięciu tomach. Red. A. Sko c z e k. T. 5: Romantyzm. Część pierwsza, rozdz. VIII: Szkoła ukraińska. Bochnia-Kraków-Warszawa [b. r.].

16 Zob. H. Kr u k ow s ka: Cykliczność „Sonetów krymskich” Adama Mickiewicza w świetle Gastona Bachelarda koncepcji czasu poetyckiego. „Bibliotekarz Podlaski” 2013, nr 2; „Genezis z Ducha”, czyli Juliusza Słowackiego medytacja o stworzeniu. W zb.: Piękno Juliusza Stowackiego. T. 3: Metamorphosis. Red. J. Ła w s ki, A. J a n i c ka. Białystok 2014-2015; Maria Dabrowska o „czarnej literaturze”. „Bibliotekarz Podlaski” 2017, nr 1; Józef Ignacy Kraszewski o miłości piękna. W zb.: Bibliotheca mundi. Prace bibliologiczne ofiarowane Janowi Leończukowi. Red. J. Ła w s ki, Ł. Zabielski. Białystok 2016. 


\section{Imperatyw}

Godność doktora honoris causa Uniwersytetu w Białymstoku przyjęła ze spokojem, lecz i z nieukrywaną dumą. Senat Uniwersytetu przyznał tę godność jej - oraz innej wielkiej osobowości polonistycznej, prof. Alinie Kowalczykowej - 20 XII $2017^{17}$. Uroczystość wręczenia dyplomu zorganizowaną 11 IV 2018 wspominała do końca. We wdzięcznej pamięci zachowywała słowa, które z tej okazji napisali o niej recenzenci. Prof. Bogusław Dopart (Uniwersytet Jagielloński) przekonywał:

Osobowość humanistyczna uczonej skłania do szczerego hołdu, podobnie głębia jej obcowania z mową wiązana, jak maksymalizm oczekiwań wobec aktu twórczego, podbudowanego skupieniem nad przepaścistą Tajemnicą ${ }^{18}$.

Prof. Marek Piechota (Uniwersytet Śląski) podkreślał jako zasadnicze dokonanie uczonej „założenie własnej, niepowtarzalnej szkoły badań historycznoliterackich (rzecz unikalną w naszej codzienności - o kilku autonomicznych pawilonach)"19. Prof. Mikołaj Sokołowski z - bliskiego sercu i pamięci Krukowskiej Instytutu Badań Literackich PAN - zauważał arcytrafnie:

Życie naukowe Pani Profesor zostało podporządkowane temu samemu imperatywowi, który ważył na działalności romantyków. Był to imperatyw zerwania zasłony z tajemnicy istnienia ${ }^{20}$.

Głosy te Krukowska przyjmowała i jako „niezasłużone pochwały”, i jako (jednak) celne ujęcia jej postawy i dokonań. Jak żartobliwie przekonywała, jej prawdziwą pasją, zrodzoną w kręgu Janion i Żmigrodzkiej, było językoznawstwo, badanie stylu poetyckiego, lecz namówiona przez swą Mistrzynię, zajęła się literaturą ${ }^{21}$.

Na emeryturze nadrabiała zaległości pisarskie, publikując interpretacje, które nam, jej uczniom, przekazywała przez lata. Ostatnim polskim twórcą, który ją fascynował pięknem polszczyzny i wspaniałą wyobraźnia, był Jan Barszczewski, autor znakomitego Szlachcica Zawalni, czyli Białorusi $w$ fantastycznych opowiadaniach ${ }^{22}$. Wysoko ceniła, bodaj najwyżej po Mickiewiczu, poezję Czesława Miłosza. Stale wracała do Krasińskiego, Słowackiego, Kraszewskiego, Żmichowskiej, Orzeszkowej, Brzozowskiego, Jaworskiego, Leśmiana, Tuwima, Dąbrowskiej, Iwaszkiewicza oraz swych ulubionych filozofek i filozofów: św. Hildegardy z Bingen, Edyty

17 Zob. wydane z tej okazji książki: Profesor Halina Krukowska. Doktor honoris causa Uniwersytetu $w$ Białymstoku. Red. J. Godlewska, A. Janicka, J. Ławski. Białystok 2018. - Profesor Alina Kowalczykowa. Doktor honoris causa Uniwersytetu w Białymstoku. Red. J. G o d l e w s k a, A. Janicka, J. Ławski. Białystok 2018.

B. D o pa rt, Opinia $w$ sprawie wniosku Uniwersytetu $w$ Białymstoku o nadanie Profesor dr hab. Halinie Krukowskiej godności doktora honoris causa tej uczelni. W zb.: Profesor Halina Krukowska, s. 42.

19 M. Pi e c h ota, Recenzja dorobku Pani dr hab. Haliny Krukowskiej w postępowaniu dotyczacym nadania Jej tytutu doktora honoris causa Uniwersytetu w Białymstoku. W zb.: jw., s. 51.

20 M. S o kołow s ki, Recenzja w postępowaniu o nadanie tytułu honorowego doktora honoris causa dr hab. Halinie Krukowskiej, profesor senior Uniwersytetu w Białymstoku. W zb.: jw., s. 53.

21 Zob. artykuł, który ukazał się po śmierci badaczki: M. Kuźmi u k, Miała być językoznawca, została ekspertka od epoki romantyzmu. „Kurier Poranny” 2019, nr z 2 VIII.

22 Krukowska przygotowywała się do napisania wstępu do edycji dzieła Barszczewskiego. Nie zdołała tej pracy ukończyć. 
Stein, Simone Weil ${ }^{23}$, Henri Bremonda, Gastona Bachelarda, Leszka Kołakowskiego, Gabriela Marcela. W centrum jej myślenia pozostawał Jan Paweł II - także jako Karol Wojtyła, poeta i dramaturg. Ceniła Josepha Ratzingera - jako znawcę muzyki i teologa. Była miłośniczką muzyki poważnej - o Bachu, Mozarcie, Chopinie, lecz też o tangu ${ }^{24}$, mogła rozmawiać bez końca.

Była osobą w najszlachetniejszym tego słowa znaczeniu samotna z wyboru, lecz nigdy nie osamotnioną. Zapytana przez dziennikarza, czy nie chciała założyć rodziny, odrzekła: „Gdyby tak się stało, moje życie potoczyłoby się inaczej. Ale strzała Amora jakoś mnie omijała, a przynajmniej nie ugodziła tak silnie, żebym straciła głowe” 25 . Twierdziła zresztą: „W moim życiu wszystko układało się tak, jakby ktoś wybrał za mnie" 26 . Nie była sama. W swoim domu w Wasilkowie żyła otoczona rodziną (siostrami), a nade wszystko czule zajmowała się ukochaną bratanica, też polonistką, Violettą Zawadzką, i jej córką Weroniką. Były one prawdziwym centrum życia Krukowskiej, im poświęcała czas i serce. Lubiła, lecz tylko z najbliższymi przyjaciółmi, ponadgodzinne rozmowy telefoniczne, które prowadziła jeszcze na szpitalnym łożu. Konferowała chętnie $z$ dr. Tadeuszem Borowskim-Besztą, prof. Aliną Myrchą, prof. Zofią Wójcicką, prof. Krystyną Ratajską oraz innymi. I w moim życiu od 2007 do 2019 roku były te rozmowy czymś naturalnym, a zarazem rytuałem.

Rzadko wyjeżdżała z Białegostoku po 2007 roku, nieczęsto kontaktowała się z kolegami, lecz z czułością mówiła o przyjaciołach, z którymi związała ją epoka studiów i początki pracy na uczelni: o prof. Józefie Bachórzu, prof. Ewie Nawrockiej, dr. Stanisławie Szczepińskim, prof. Małgorzacie Czermińskiej. Zawsze powracała do postaci przedwcześnie zmarłego - jak podkreślała - „wybitnie utalentowanego” dr. Zbigniewa Suszczyńskiego, jej ucznia. Prowadziła regularnie odczyty w szkołach, wygłaszała referaty na białostockich konferencjach. Martwiła się tzw. reformą nauki i jej niszczącym wpływem na humanistykę w ośrodkach takich, jak Białystok. Do roku 2018 wygłaszała - zawsze $z$ najwyższa pasja - wykłady o Mickiewiczu i Malczewskim. Ostatnie - w białostockim KIK-u, I LO i w VIII LO im. Króla Kazimierza Wielkiego w Białymstoku, gdzie mówiła o poezji czystej w Panu Tadeuszu ${ }^{27}$.

Zawsze i wszędzie podkreślała, że jest z Podlasia, z Białegostoku, ze swego ukochanego Wasilkowa.

Nigdy nie zwątpiła w sens pracy, sens życia. Uwielbienie sztuki i zabarwiona mistycznie wiara, niebywała klarowność myślenia i prostolinijność wyróżniały Profesor Krukowską, czyniły ją osobowością o niezwykłej sile promieniowania

Polski. Seria 4: Uczeni żydowscy. Red. G. Czerwiński, J. Ławski. Białystok 2016.

24

Tej pasji Krukowskiej poświęcono rozprawę: R. G aj, Filozofia tanga. W zb.: Światto $w$ dolinie.

Humanistka. Z prof. Halina Krukowską rozmawia Jerzy Szerszunowicz. „Kurier Poranny” (Magazyn) 2007, nr z 19 X, s. 10.

Ibidem.

Z młodzieżą VIII LO w Białymstoku spotkała się na zaproszenie dr Grażyny Dawidowicz 28 IX 2018. Na sesji ostatni raz wystapiła 9 XI 2018 - z tezami „Romantyczność” Mickiewicza jako tekst kulturowy (Jubileuszowa Międzynarodowa Konferencja Naukowa: W 200 rocznicę debiutu poetyckiego Adama Mickiewicza: 1818-2018 „Debiuty Mickiewicza, debiuty romantyków. Tradycje - strategie - idee-język". PAU-UwB. Białystok, 9-10 XI 2018). 
i przyciagania. Życie uważała za metafizyczną tajemnicę. Nigdy nie spotkałem kogoś, kto tak doskonale wiedziałby, kim jest, czego chce, a czego nie chce, co się powinno uczynić. Była wzorem, prawdziwą Mistrzynią, otoczoną czułym szacunkiem przyjaciół i uczniów. W jednym z ostatnich wywiadów, mówiła z ogromną siłą przekonywania:

Jestem optymistką i myślę, że humanistyka nigdy nie upadnie, bo człowiek bez wiedzy humanistycznej staje się robotem. Dusza musi objawić się wszędzie, na Politechnice czy na innych studiach. Do tego muszą doprowadzić wykształceni humaniści. Jeżeli widzimy, że ktoś jest utalentowany, trzeba to traktować jako najwyższy skarb. Nie ma innego wyjścia ${ }^{28}$.

Chorobę znosiła z pokorą, wierząc prawie do końca, iż uda się ją jeszcze pokonać. $Z$ odejściem Profesor Krukowskiej zakończyła się cała epoka białostockiej polonistyki. Wielu, ja także, straciło Mistrzynię i wspaniałą Przyjaciółkę we wszelkich dolach i niedolach życia.

Od roku 2017 - aż do ostatnich dni - pracowała nad esejem o przejrzy s toś c i w Widzeniu Adama Mickiewicza.

Jarosław Ławski

Uniwersytet w Białymstoku - University of Białystok ORCID: 0000-0002-1167-5041

Białystok, 14 IX 2019

Abstract

OBITUARY: HALINA KRUKOWSKA (September 26th, 1937-July 28th, 2019) A REMEMBRANCE

The remembrance is devoted to professor Halina Krukowska, Romantic literature researcher, her entire academic life affiliated to the Białystok philological centre. A Maria Janion disciple, Krukowska's interest were the motif of the night in 19th century literature and the Black Romanticism trend in the Polish and European literature. 